\title{
CYPRIOT MUSLIMS AMONG OTTOMANS, TURKS AND TWO WORLD WARS
}

\author{
ILIA XYPOLIA* \\ Keele University
}

\begin{abstract}
This article focuses on the secular Turkish identity that was being shaped during the interwar period. It examines the cleavages within the Muslim community of Cyprus and explores the formation of the Turkish Cypriot national identity. The main argument of this paper is that the rift in the Muslim community during the interwar period was a reflection of the conflict between the reformist and traditional trends that was taking place at the same time in the Republic of Turkey.

During the interwar period, 1919-1939, the Muslim community of Cyprus was divided between the secularist and the traditional Muslims. As in Turkish society in the 1920s, the Turkish Cypriot community was dominated by the so-called traditional Muslims. Only the Muslim elite minority favored Kemal Atatürk's secular views. The British colonial rule cooperated more with traditional elites. At the same time secularist Muslims were cooperating with Greek Cypriots in economic issues. The 1930s was the crucial decade in the development of a Turkish Cypriot secular identity. This internal conflict of the Muslim community was terminated after World War II, with the victory of the secularists.
\end{abstract}

Keywords: Cyprus, nationalism, national identity, religion.

\section{OSMANLILAR, TÜRKLER VE IKİ DÜNYA SAVAŞI ARASINDA KIBRISLI TÜRKLER}

\section{ÖZET}

Bu makale iki dünya savaşı arasındaki dönemde şekillenen seküler Türk kimliğine odaklanmaktadır. Kıbrıs Müslüman toplumunun iç kırılmaları ele alınarak Kıbrıslı Türk kimliğinin oluşumu açıklanmaktadır. Makalenin ana argümanı, Kıbrıs Müslüman toplumunun iki dünya savaşı arasındaki dönemde yaşadığı ayrışmanın Türkiye Cumhuriyeti'nde aynı dönemde yaşanan reformcu ve gelenekçi trendler arasındaki çatışmanın bir yansıması olarak tezahür ettiğidir.

İki dünya savaşı arası dönemde Kıbrıs'taki Müslüman nüfus henüz tam bir ulusal birlik içinde değildi. Sekülerleşme taraftarı olanlar ve geleneksel düzen yanlısı olanlar arasında bir ayrım vardl. Sadece elit bir Müslüman azınlı Kemal Atatürk’ün seküler görüşlerini tercih etmekteyken, Ingiliz sömürge

* Ilia Xypolia is a Ph.D. candidate in the School of Politics, International Relations and Philosophy at Keele University, Keele, Staffordshire, ST5 5BG, UK. E-mail: iliaxypolia@gmail.com

Boğaziçi Journal Vol. 25, no. 2 (2011), pp. 109-120. 
hükümeti geleneksel seçkinlerle işbirliği içindeydi. Aynı zamanda sekülerleşme yanlısı Müslüman nüfus, iktisadi konularda Kıbrıslı Rumlarla işbirliği yapmaktaydı. 1930lu yıllar seküler bir Kıbrıslı Türk kimliğinin gelişmesinde en önemli yıllar oldu. Kıbrıs'ın Müslüman toplumu arasındaki “iç çatışma” İkinci Dünya Savaşı'nın bitmesi ile sekülerleşme taraftarlarının zaferi ile sona erdi.

Anahtar kelimeler: Kıbrıs, milliyetçilik, milli kimlik, din.

Engels (1978) writing on the philosophy of history held that the periods of non-conflict are the blank pages in history. This could be true in the case of the Turkish Cypriot politics. If one considers the gallons of ink that has been spilled over the history of Cyprus, almost nothing has been written about the interwar period. However, during this period a major transformation took place in the identity of the Muslim community of the island, a shift from a primarily religious to a national identity.

Certainly Turkish Cypriot politics during the period of the British rule in Cyprus has not been the most popular field of research. Even the scholars that are engaged with the Cyprus issue tend to focus on the Greek Cypriot politics of the period, ignoring the interesting dynamics of the Muslim Cypriot community.

Cyprus, the largest island in the Eastern Mediterranean, had received colonists from all the ancient empires of the region since antiquity, not least because of its geostrategic importance. In 1571 the island became part of the Ottoman Empire and the former was incorporated into the framework of Ottoman rule. Since then the Ottomans transferred population from Anatolia to inhabit the island. The Muslims of the island were part of the dominant millet. ${ }^{(1)}$ The Christians were also recognized as a separate millet. There are conflicting estimates for the composition of the Cypriot population during the Ottoman era (Hill, 1952). It is interesting that Kyprianos (1971), a historian of Greek Cypriot origin, argued that in the 18th century the number of Muslims exceeded that of the Christians. The cleavages between the ruling elite (both Muslim and Christian), the peasantry (both Muslim and Christian), and a limited middle sector of local craftsmen torn between the two were more basic than the institutional and religious differences between Muslims and Christians. It was a class society, where class relations, identities and conflicts superseded all others.

To trace the ethnic origins of Muslim Cypriots only in the immigration of the Muslim populations from Anatolia is probably inaccurate. During the Ottoman epoch in Cyprus numerous Christians converted to Islam for socio-economic reasons. ${ }^{(2)}$ Following the act of the religious conversion, the convert immediately became part of the dominant Muslim millet. However, there were a large number of those converts who remained secretly Christians. The so-called Linovamvaki ${ }^{(3)}$ passed through a crypto-Christian stage to Islam during the period of the Ottoman rule and remained Muslims even after the advent of the British rule because the powerful Church of Cyprus did not accept them back (Gürkan, 1986: 39). Additionally, there are many reports of inter-marriages between Muslims and Christians during the Ottoman rule in Cyprus.

Cyprus experienced imperialism under British colonial rule which started in 1878 and ended in 1960. Greek and Turkish nationalism developed at different historical periods and at different paces. Greek nationalism started at the beginning of the 19th century before the advent of British Colonialism while Turkish nationalism started to develop in the Ottoman Empire at the end of 19th century and was 
made fully real with the establishment of the Republic of Turkey in 1923. Relations between Turkish Cypriots and the British on the one hand, and Greek Cypriots and the British on the other, were asymmetrical. During the colonial era in Cyprus, the Muslim community had undergone an enormous change in terms of national/ethnic identity and class characteristics. Turkish Cypriot nationalism developed belatedly as a militant nationalist and anti-Enosis movement in the 1950s.

In 1878 the island passed to the administrative authority of the British Empire, under the suzerainty of the Sultan. However, the change from the Ottoman to the British rule was not translated into a modern administration system as the British did not transform the Ottoman system (Georghallides, 1979: 34). In 1914, because the Ottoman Empire entered the First World War on the side of the Central Powers, Britain officially annexed Cyprus. The Muslims of Cyprus welcomed the annexation by affirming their loyalty to the British rulers (Attalides, 1979: 41). Turkish scholars attributed the stance of the Muslim community of Cyprus to the feeling of abandonment by Turkey and the awareness of Turkey's weakness. However, after the annexation the Cypriot Muslims lost their special status that had been derived from the Sultan's nominal sovereignty. Just after the First World War and followed by the Greek-Turkish war of 1922, the modern state of Turkey emerged. Questions of identity arose in the early twentieth century among the Muslims in the Ottoman Empire: Turkish, Ottoman or Muslim (Landau, 1995). There was no sign of Turkish nationalism in Cyprus until the early 1920s. When we are examining Turkish Cypriot nationalism, we should always bear in mind the fact that Turkish nationalism was the last to develop in the Ottoman Empire. Thus the Muslim community of the island did not have a mainland nationalist movement to attune to until the Young Turk Revolution of 1908. But even then (or when the Young Turks' Revolution was broken) there was little response from the Muslims of Cyprus.

The interwar period, which is the period under question, represents one of the most interesting historical periods of the 20th century. It was a period marked by the Great Depression in 1929, the New World Order, as well as the end of the British Empire. The British Empire was still a pre-eminent world power but undergoing a huge decline. This fact had serious repercussions on Cyprus and the British colonial policy there. Prior to the period in question Britain had offered Cyprus to Greece three times, all unsuccessfully. These years were extremely important in the political history of the island because it was then that the Muslim community began its identity transformation from a religious one to a national.

The aim of this article is to explore this process that made the Cypriot Muslim community embrace Atatürk's reforms while it was left outside of the borders of the newly established Turkish Republic. The main channel through which the new Turkish Kemalist ideology was spreading in Cyprus was the Turkish Consulate. However, until the Turkish national archives become accessible to the scholars we can only base our conclusions on the British documents.

Atatürk's political and cultural reforms were the two sides of the same coin that aimed at the modernization of the Turkish Republic. The abolishment of the Caliphate in 1924 came along with revolutionary changes that included a new alphabet, a new dress code and a major revision of the family law. This article suggests that the introduction of these reforms met an opposition by the majority of the members of the Muslim Cypriot Community during the interwar period.

We will briefly give a historical background of the conflict in the Republic of Turkey. Then the two Cypriot rivals will be presented in order to proceed to the analysis of their conflict in two arenas. The 
political and the cultural arena actually comprise the two sides of the same coin that was successfully used by Atatürk in order to buy a ticket towards modernization.

The Kemalist ideology was elaborately analyzed in the notable Nutuk, the 'six days speech' of Kemal Atatürk at the General Congress of the Republican Party in 1927 (Atatürk, 2008). His ideology was constructed on six main principles or values, namely Nationalism, Republicanism, Statism, Populism, Revolutionalism and Secularism that have been illustrated in the six arrows of the symbol of his Republican Party. These six values were the road map for the Republic of Turkey towards the modernization and the westernization of the state and the society. These values and principles were disseminated limitedly among the Cypriot Muslim Community through the system of education and the activities of the Turkish Consulate.

The liberal educational policy adopted by the British up until the 1920s permitted the young generation of the Cypriot Muslims to be educated following the official curriculum of the Republic of Turkey. However, the disturbances of 1931 were the ideal pretext for the British rule to become authoritative, ruling by decree and abolishing the Constitutional order.

\section{INTERNAL DIVISION}

The religious vs. the secular struggles that are apparent today in contemporary Turkish politics date back to at least the late 19th century. The struggles between religious and secular agents have involved different goals and strategies. From the end of the 19th century in the declining Ottoman Empire, Young Turks opposed the monarchy of the Sultan and supported the re-installation of the constitution of 1876, seeking a progressive path to modernization. Turkish nationalism began to be developed at the end of 19th century but in the beginning of the 20th century it took on a more political character and was transformed into a political movement. The Turkish nationalist project that the Republic of Turkey undertook aimed at the homogenization of the population.

The Muslim community of Cyprus was not homogeneous during the period in question. In Cyprus the traditionalists figured prominently in the religious oppositions to Atatürk's reforms and they enjoyed a large influence even after World War II. The British collaborated with the traditional Evkafçılar section of the Muslim community. Until the 1930s, on nearly every occasion that the Greek Cypriots submitted a petition or passed a resolution calling for Enosis, the Muslim Cypriots either remained neutral or responded with a demand that there should be no change in the status of the island, thus demonstrating their loyalty to British rule. Through loyalty to the British administration and the Islamic solidarity Muslim Cypriots expressed their fear that they would be dominated by their Greek compatriots (Attalides, 1979).

The two rivals in the Muslim Community were the so-called Evkafçılar and the Halkçılar (Kızılyürek, 1999). These two camps were also identified as the Evkaf who were the conservative traditionalists in favor of the status quo, and the Kemalists who were the progressive reformists. From the late 1920s the two prominent leaders of the community were Münir Bey and Nejati Özkan along with the Turkish Consul representing respectively the traditionalist and the Kemalists. Münir Bey was the leading personality in the politics of the community for two decades. He represented the traditionalist and the so-called Evkafçılar section of the community. According to British officials, Münir was totally pro-British and had "the mentality of an old Turkish pasha" (C0 67-247-13). He had absorbed 
into himself every office he could. Nonetheless the British Governors saw him as the best collaborator and appointed him the Delegate of the Evkaf institution and a member of the Executive Council when, at the same time, he was elected as a Legislative Councilor.

Prior to his appointment as the Director of the Evkaf, Münir Bey had served for many years in the Accounting Branch of the Treasury and as a judge of the District Court. Münir Bey was a barrister at law, one of the Public Loan Commissioners, a member of the Irrigation Board and of the Muslim Board of Education. He was the nephew and son-in-law of the Müftü (Mufti) and a very respectable person in the Cypriot society. He had a good deal of influence with the Cypriot Muslims and was entirely pro-government. He was appointed as a member of the Executive Council and his advice "was generally sound and [he] has good knowledge of local conditions" (CO 67-233-14). He was undoubtedly a very valuable man for the British (CO 67-233-14).

On the other side of the spectrum, in the emerging Kemalist trend within the Muslim community, Nejati Özkan was the unquestioned leader for the Kemalists. In addition, the Turkish Consulate that was established in 1925 in Larnaca was the main channel of spreading the Kemalist ideology among the Muslim Cypriots. The Turkish Consul was critical of the stance of the traditionalists who were collaborators with the British rule. He was hostile to the administration of the Evkaf (CO 67-262-2).

Having said that, let us turn the attention to the scenes of action where the conflict took place. The battle was played mainly in two different arenas, the political and the cultural. There the two camps clashed over different goals and ends. Let's now proceed to examining each battlefield.

\section{Political Arena}

In 1925 Cyprus became officially a Crown Colony and Turkey established its Consulate on the island (McHenry, 1987). Actually, by the provisions of Article $16^{(4)}$ of the Treaty of Lausanne that caused a big debate, especially in the 1950s Turkey renounced all her rights in Cyprus. Kemal Atatürk's Turkey encouraged the Muslims of Cyprus to migrate and resettle in Anatolia in order to homogenize the population of the newly founded Republic of Turkey. ${ }^{(5)}$ In December 1925, there was the settlement of approximately 5,000 Muslim immigrants from Cyprus to Turkey. However, a report of 1928 claimed that many Muslims who had immigrated from Cyprus to Turkey in previous years, had returned. The population who had emigrated from Cyprus to Anatolia chose to go back to Turkey because of the prospect of better living standards (CO 323/1213/8). But eventually the vast majority of the emigrants went back to the island because the conditions they faced in Turkey were worse than the political and religious liberties they had under the liberal British administration (CO 67/221/11).

The election in 1930 was a major turning point for the politics and the political balance in the Muslim Cypriot community. At the elections that were held on October 1930, the Kemalist and progressive Nejati Özkan Bey was elected to the Legislative Council, taking the place of the traditional and proBritish Münir Bey (Kizılyürek, 1999: 57). Nejati Bey fought for the rights and the interests of his community and he supported the release of the British control of the Evkaf and the election of the Müftü by his community rather than by an appointment by the British Governor. He was definitely against Enosis but he voted on the side of the Greeks only when he thought that it was in favor of the Muslim community (Nevzat: 2005: 17). 
The Governor Sir Ronald Storrs in his memoirs highlighted the role of the Turkish Consul Assaf Bey in spreading the Kemalist ideology among the members of the community (Storrs, 1939: 588). The Turkish Consul was in close touch with the Editor and proprietor of the Kemalist local newspaper Söz, Remzi Effendi (CO 67-262-2). In 1930 Söz published various reports attacking Münir Bey's proBritish stance. The Turkish Consul interference in the local affairs caused dissatisfaction among the British officials (CO 67-275-10). There political enmity between the Turkish Consul and Münir Bey was often reported in the Turkish Cypriot nationalist press of Söz, Hakikat and Vakit that were the link between Turkey and Turkish Cypriot community and affirmed the loyalty of the latter to Kemalism. (McHenry, 1987: 140) According to a secret dispatch from Governor Palmer, the Turkish Consulate funded the newspaper Söz the sum of $£ 18$ a month (CO 67-291-10).

The rivals often sent petitions to the British Government. The most interesting fact was that the Kemalist faction of the community was pre-occupied with the rivalry with the Evkaf institution and Münir Bey, and any opposition to or hostility against the Greek Cypriots was secondary. So preoccupied was the Kemalist newspaper Söz with its opposition to Münir Bey and his policies that this priority often undermined the newspaper's opposition to the Greek Cypriot cause. Nevertheless the Kemalists were loyal to the British Government only when they wanted to avoid the Greek Cypriot invitation for cooperation. They affirmed that it was impossible for them to cooperate in any action which was incompatible with the consent and wishes of the Government (SA1 517/1928/2- Söz, No.605, dated 15.9.1933).

The Kemalists were persistent in their refusal to recognize Münir Bey as the leader of the community. Especially after the abolishment of the Constitution and the Legislative Council, there were no elections in the 1930s to give evidence of the popular support for Münir Bey. The Kemalists argued that Münir Bey was not the Head of the Community as he was appointed the Director of Evkaf which was a department of the Government (SA1 517/1928/2 Söz, No.713, dated 21.1.1934). Nejati Özkan, the prominent leader of the Kemalist faction, sent a petition to the Colonial Government arguing that it was unjust to consider the Delegates of the Evkaf as the representatives of the Muslim community who were entitled to speak on behalf of the whole community (SA1 517/1928/2- Söz, No.591, dated 1.6.1933).

In 1933, in anticipation of a visit from the Conservative Minister Sir Phillip Cunliffe-Lister to Cyprus, the Kemalist agents within the community prepared to present themselves to the British Secretary of State for the Colonies. The Kemalist newspaper Söz seized the opportunity and argued that the Director of the Evkaf was not the representative of the Muslim Cypriots, calling on fellow citizens to "abstain from signing any document which may be presented to them by the Evkaf party to the effect that they are satisfied with the present organization" (SA1 517/1928/2- Söz, No. 672, dated 2.12.1933).

On a regular basis, Münir Bey reported to the Governor of Cyprus that the Turkish Consuls in Cyprus considered the Evkaf institution as a block to their aims to speak for the Muslim Cypriots. Münir Bey held that one who was loyal to the British Government was not necessarily anti-Turkish (C0 67-2622). In 1931 Münir Bey asked the Governor Ronald Storrs to make an enquiry about Judge Raif in regard the allegations of his meddling in local politics. Raif Efendi, ${ }^{(6)}$ District Judge at Nicosia and Kyrenia, was accused of taking part in local politics. He had grievances against Münir Bey and several police officers and considering them as his enemies who were persistently trying to injure him (CO 67238-11). However, Storrs decided not to make a judicial enquiry as he thought it would not serve any 
useful purpose. This bitter personal vendetta between the two prominent Turks was not of paramount importance to the British.

An interesting and indicative case of the internal conflict within the Turkish Cypriot community took place in 1935. Münir Bey took the liberty to communicate directly with Sir Philip Cunliffe-Lister, the Secretary of State for the Colonies. In his secret letter, Münir Bey complained about the interference by the Turkish Consul in respect to his nephew Ertuğrul Işınay. Münir Bey accused the Turkish Consul of using his political enmity towards Münir Bey's family in order to compel Münir Bey to fall more in line with the Turkish Consul's political views. In particular Münir Bey accused the Turkish Consul of requesting the Turkish Government to expel Ertuğrul from the Military Veterinary College at Ankara (CO 67-262-2).

In 1937 the debate on the new Cyprus Constitution was still going on. In the Kemalist agenda concerning the prospect of a new Constitution, the perception of the threat of a Greek Cypriot dominance was prevalent. Söz published an article on that issue highlighting the issue of defense that perceived the Greek Cypriot as a threat: "Then comes the question of defense. To attribute the present tranquility and security to our own powers would be an absolute fallacy. If it is intended to leave the responsibility of defense to Great Britain, this will certainly involve submission to her power and authority, in which case we shall have to seek the ways of our local progress and development" (SA1 517/1928/2).

The Kemalists opposed Evkaf policies and were constantly sending letters to the British rule calling them to consider their concerns. They addressed the British officials claiming that they, the Kemalists, were the real representatives of the community. Their main issue and objection that they raised in their correspondence with the Government was the participation of the Turkish Delegate of the Evkaf Department in politics. They argued that the Delegate of the Evkaf as a Government official had insufficient time to look after the affairs of the community, and he could not defend the rights of the people in cases where the interests of the Government and of the Community might clash (SA1 517/1928/2- Söz, No.584, dated 26.5.1933).

Moreover, the emerging secular Cypriot Muslims criticized Münir Bey also for economic issues regarding the administration of the Evkaf (SA1 533/1931). There were certain criticisms about the benefit of Evkaf funds used for the Muslim Community. The Evkaf Department frequently used its funds in order to erect minarets in some villages that considering the harsh times, in the eyes of the Kemalists were nothing but luxury. Also the Religious Schools that the Evkaf were investing money in were seen by the Kemalist as totally unnecessary. They argued that instead of establishing religious schools, a special course in the Lycee for those who were willing to be trained for the posts of Imam and Preacher could be organized. The Kemalists suggested that the appropriation of the Evkaf Funds should not be at the discretion of its delegates. They asked that the annual Evkaf estimates should be framed by a body that included the representatives of the people, and that any surplus should be utilized for religious, charitable and educational purposes (SA1 517/1928/2- Söz, No.584, dated 26.5.1933).

\section{Cultural Arena}

As we mentioned above, Atatürk's reforms in the 1920s attempted to achieve nothing less than a cultural revolution. In the early years of the Republic of Turkey, many innovative reforms were introduced, changing, inter alia, the alphabet, the dress code, and the family law. The emerging 
secular opposition was in favor of the adoption of Kemal Atatürk's reforms and actively promoted them, while the conservative traditionalists strongly opposed them.

The Kemalists strongly advocated for the establishment of a Muftiship in order to acquire the spiritual head of the community. The Müftü's duty would not be simply to issue Fetvas (canonical opinions) but also to represent the community as its spiritual head. The Kemalists were arguing that the delegates of the Evkaf appeared to have wrongly assumed this right, while their duty should have been only to administer the Evkaf Department which the former perceived just as a financial institution (SA1 517/1928/2- Söz, No.581, dated 25.5.1933).

Actually the Turkish Consul was pressing the British Government to accept the reforms in the law on polygamous marriages (SA1 766/1935). However, the British were reluctant in the 1930s to encompass these reforms not least because of the discontent that they would cause. For instance, when in 1933 a Judge from the District Court in Nicosia suggested that the divorce law should be altered, the Colonial Office was unwilling to implement that reform because "it would meet with the strong opposition of the Muslim community as being an interference with their religion" (SA1 844/1933).

It is interesting enough that even the newspaper Masum Millet that was constantly opposing Evkaf's policies and was considered to be siding with the Kemalist section of the community was being published in the Arabic alphabet even in the 1930s. This choice can be explained if we consider that the shift from the Ottoman to the new Turkish alphabet was not adopted immediately by the members of the Muslim Cypriot community, especially its elderly members. This fact was often criticized by the leading Kemalist newspaper Söz writing that "we see Masum Millet is increasingly scattering microbes and attacking every honest person in the country. This paper is vulgarly attacking the Koran, and at the same time is being published in Koranic (Arabic) characters. The paper is full of grammatical mistakes" (SA1 517/1928/2- Söz, No.624, dated 7.10.1933).

Though the two newspapers Söz and Masum Millet were the voices of the Kemalists, Söz many times published articles criticizing Masum Millet's columns on the ground that the latter published wrong ideas and suggestions. On the issue of the Müftü, Söz saw the stance of Masum Millet to be flawed when it wrote that a Müftü was not required (SA1 517/1928/2- Söz, No.603, dated 24.8.1933).

Actually the Turkish Consul was pressing the British Government to accept the reforms in the law against polygamy (CO 67/268/4). Despite the fact that the British were reluctant in the 1930s to accept these reforms, gradually the Cypriot Muslims embraced them. Regarding the use of the fez in Cyprus a paradox occurred. Although in Turkey the $f e z$ was an Ottoman symbol and was abolished by the Kemalist reforms, in Cyprus the use of the fez was popular throughout the period in question and was perceived as a Turkish symbol. It is of interest that the Greek Cypriots grasped that wearing the $f e z$ presented a Turkish appearance (CO 67-239-14). After all, the official version of Turkish nationalism under the Republic was different from the actual operative ideals and loyalties of the Muslim Cypriots. It was only after World War II that Kemalism became apparent in every aspect of life within the Turkish Cypriot community.

Söz incessantly promoted the new image of the Turk and actively opposed the fez. For instance, in 1933 Söz published an anonymous letter addressed to the Editor of Söz criticizing the fez wearing leaders of the Muslim community: 
“....with reference to the two photographs inserted in the previous issues of your paper, showing the Turks bidding goodbye to His Excellency Sir Reginald Edward Stubbs at Larnaca, I protest against your lines below each photograph describing the Turks seen in them as the representatives of the Turkish Community. Those Turks wore fezzes or turbans while all the Turkish youth and the majority of the Turkish people in Cyprus wear hats. I do not wish to criticize those gentlemen for their head dresses, as we are living in a country which enjoys liberty, but I wish to point out that the headdress of the Turkish Community in Cyprus is hat and it can be represented only by persons who wear hats. A Turk from Nicosia" (SA1 517/1926/2- Söz, No.682, dated 14.12.1933).

Then the Editor of Söz commented that "we admit our mistake in publishing the lines refered to and are glad to see that the press is being controlled by our youth" (SA1 517/1926/2- Söz, No.682, dated 14.12.1933).

The wearing of hats by the Muslim school boys alerted the Kadl (judge in a Muslim community) of Cyprus. In 1925 the Kad $\iota$ sent a letter to the Chief Inspector of Schools requesting that "the present costumes of the Students may not be allowed to be changed at all on account of the political and special attitude of Cyprus unless a Fetva is issued by His Eminence the Müftü of Cyprus and unless a decision is obtained from the Muslim Board of Education and the Governing Body" (SA1 969/1925).

Söz also pressed the Government to enact a modern law regarding wills. In 1933, Said Hoca, a former member of the Legislative Council, sent an open letter to the Governor suggesting that a modern law on wills should be enacted for the Muslim Community in Cyprus embodying provisions that would be compatible with Sheria principles (SA1 517/1928/2- Söz, No.590, dated 26.5.1933).

The new family law had a paramount importance in the modernization process adopted by Kemalist Turkey. The emerging secular fraction of the Muslim Cypriot community was anxious to adopt the new family law also in Cyprus. At a time when the Republic of Turkey had adopted the Swiss law, it could not be justified for the Kemalist section of the Muslim Cypriots to continue with a law which was framed 1260 years before and in their view could not satisfy their requirements (SA1 517/1928/2Söz, No.613, dated 24.9.1933). However, the majority of the members of the community did not want any reform in the family law. It is indicative that in 1933 a report from Charles Abbott, President of the District Court of Nicosia, called for the need for a legislative reform in the divorce law of the Muslim community. In reply, Governor Stubbs wrote that the suggestion that the Muslim law of divorce should be altered would meet with strong opposition from the Muslim community (SA1 844/1933).

Finally one very important issue that caused a lot of debate was the use of alcohol. The 'Kardes Oca $\breve{g l}$ ' Club in Nicosia in 1936 amended its constitution in order to be able to sell alcoholic beverages. "Up to the present date, the use of intoxicating drinks on the Club premises was prohibited. The rule imposing this prohibition was deleted and a resolution was passed authorizing the Club to obtain a license for the sale of drinks" (SA1 517/1928/2- Söz, No.919, dated 14.1.1936). This fact met the strong opposition of the conservative fraction of the community who asked the British Administration to intervene. 


\section{CONCLUSION}

The politics of Cyprus throughout this period were part of a bigger story. One cannot really understand political and social developments in Cyprus unless one sees them in the context of developments within the region of the Eastern Mediterranean and especially of the former Ottoman lands. This is especially true of the shape of national identity and the growth of nationalism. These should not be examined in isolation, nor in a purely Anglo-Cypriot context. The political, social and cultural interchange with the developments that were taking place at the same time in the Eastern Mediterranean was of major importance to the culture and politics of the entire region.

After the Second World War, Cyprus experienced inter-communal fighting during her de-colonization process. Understanding the development of the Turkish nationalism during the interwar period enables us to have a greater understanding of the postwar Cypriot politics. Thus the analysis of the interwar period allows a longer term perspective on Turkish nationalism, and makes it possible to evaluate how much of its rapid growth and militarization were due to interwar developments.

\section{NOTES}

1. In Turkish, millet means religious community. The Ottoman Empire used the millet system, which granted minority religions the freedom to establish their own set of laws and system of taxation. Under the millet system non-Muslims were granted autonomy to manage their own personal and religious affairs so long as they swore loyalty to the Empire

2. The act of religious conversion from Christianity to Islam was changing the social status of the individual. He changed from being an infidel taxpayer into a Muslim taxpayer, which meant he paid fewer taxes.

3. Linovamvakoi comes from the words linen and cotton meaning that those people were different in appearance (Muslims) than what they really were (Christians).

4. Article 16 in the Lausanne Treaty: Turkey hereby renounces all rights and title whatsoever over or respecting the territories situated outside the frontiers laid down in the present Treaty, and the islands other than those over which her sovereignty is recognized by the said Treaty, the future of these territories and islands being settled or to be settled by the parties concerned. The provisions of the present Article do not prejudice any special arrangements arising from neighborly relations which have been or may be concluded between Turkey and any limitorphe countries.

5. The Article 21 of the Treaty of Lausanne provided that: Turkish nationals ordinarily resident in Cyprus on 5 November 1914 will acquire British nationality subject to the conditions laid down in the local law, and will thereupon lose their Turkish nationality. They will, however, have the right to opt for Turkish nationality within two years from the coming into force of the present Treaty, provided that they leave Cyprus within twelve months after having so opted.

Turkish nationals ordinarily resident in Cyprus on the coming into force of the present Treaty who, at the date, have acquired or are in process of acquiring British nationality, in consequence of a request made in accordance with the local law, will also thereupon lose their Turkish nationality. 
It is understood that the Government of Cyprus will be entitled to refuse British nationality to inhabitants of the island who, being Turkish nationals, had formerly acquired nationality without the consent of the Turkish Government.

6. Raif Efendi was the father of the Turkish Cypriot leader Rauf Denktaş.

\section{REFERENCES}

An, A. (2006). Kıbrıs Türk Toplumunun Geri Kalmışlı̆̆ı 1872-1962. Kyrenia: Shadi Enterprise Ltd.

Atatürk, M. K. (2008). The Great Speech. Ankara: Atatürk Research Center.

Attalides, M. A. (1979). Cyprus. Nationalism and International Politics. Edinburgh: Q Press.

Beckingham, C.F. (1957). "Islam and Turkish Nationalism in Cyprus," Die Welt des Islam, 5(1/2): 65.

Engels, F. and Marx, K. (1978). The Marx-Engels Reader. Norton: New York.

Georghallides, G. (1979). Cyprus and the Governorship of Sir Ronald Storrs: The Causes of the 1931 Crisis. Nicosia: Zavallis Press.

Gökalp, Z. (1959). Turkish Nationalism and Western Civilization. Selected Essays of Ziya Gökalp. London: George Allen and Unwin Ltd.

Gürkan, H. (1986). Bir Zamanlar Kıbrıs ‘ta (Once Upon a Time in Cyprus). Nicosia: Cyrep Yayınları.

Hill, G. (1952). A History of Cyprus. Vol. IV. Cambridge: Cambridge University Press.

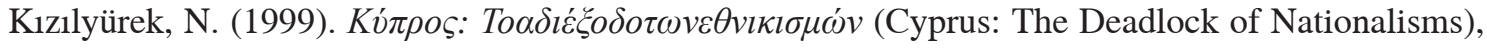
Athens: Mavri Lista.

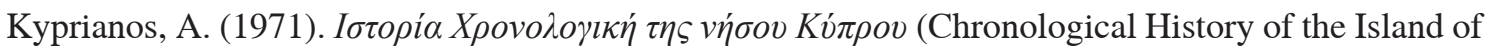
Cyprus). Nicosia: Ekdosis Paliggenesias.

Landau, J. (1995). Pan-Turkism from Irredentism to Cooperation. London: Hurst.

McHenry, J.A.J. (1987). The Uneasy Partnership on Cyprus, 1919- 1939: The Political and Diplomatic Interaction between Great Britain, Turkey, and the Turkish Cypriot Community. New York and London: Garland Publishing, Inc.

Nevzat, A. (2005). Nationalism amongst the Turks of Cyprus: The First Wave. Oulu: Oulu University Press.

Samani, M.O. (1999). Kıbrıs Türk Milliyetçiliği (Turkish Cypriot Nationalism). Istanbul: Bayrak

Storrs, R. (1939). Orientations. London: Readers Union LTD. 


\section{Archival Material}

The National Archives, London, UK.

The Republican Archives, Ankara, Turkey.

The State Archives, Nicosia, Cyprus. 